\title{
Malfunction of Vascular Control in Lifestyle-Related Diseases: Mechanisms Underlying Endothelial Dysfunction in the Insulin- Resistant State
}

\author{
Kazuya Shinozaki ${ }^{1}$, Kazuhide Ayajiki ${ }^{1}$, Atsunori Kashiwagi ${ }^{2}$, Masahiro Masada ${ }^{3}$, and Tomio Okamura ${ }^{1, *}$ \\ ${ }^{I}$ Department of Pharmacology and ${ }^{2}$ Department of Medicine, Shiga University of Medical Science, \\ Otsu, Shiga 520-2192, Japan \\ ${ }^{3}$ Laboratory of Biochemistry, Faculty of Horticulture, Chiba University, Matsudo, Chiba 271-8510, Japan
}

Received October 13, 2004; Accepted October 29, 2004

\begin{abstract}
It is tempting to speculate that increased vasoconstriction and loss of endotheliumdependent vasodilation might be etiological factors of elevated blood pressure in the insulinresistant state. Vascular contraction induced by angiotensin II and the expression of NAD(P)H oxidase were increased in the aorta of insulin-resistant mice. In addition, both angiotensin II type 1 receptor expression and superoxide anion production were up-regulated in these mice. Another mechanism for imparing endothelial function is the uncoupling of endothelial nitric oxide synthase (eNOS). It has become clear from studies on the aorta of insulin-resistant rat that insulin resistance may be a pathogenic factor for endothelial dysfunction through impaired eNOS activity and increased oxidative breakdown of NO (nitric oxide) due to an enhanced formation of superoxide anion (NO/superoxide anion imbalance), which are caused by relative deficiency of tetrahydrobiopterin, a cofactor of NOS, in vascular endothelial cells. Supplementation of tetrahydrobiopterin restored endothelial function and relieved oxidative tissue damage through activation of eNOS in those rats. These results indicate that generation of superoxide anion from $\mathrm{NAD}(\mathrm{P}) \mathrm{H}$ oxidases and an uncoupled eNOS may be pathogenic factors for impaired endothelial function and hypertension in the insulin-resistant state.
\end{abstract}

Keywords: insulin resistance, endothelial dysfunction, renin-angiotensin system, nitric oxide, pteridine

\section{Introduction}

Accumulated evidence indicates that vascular insulin resistance has a pathogenic role in endothelial dysfunction $(1-5)$. Binding of insulin to its receptor results in an activation of insulin receptor tyrosine kinase, which in turn, phosphorylates tyrosine residues of insulin receptor substrates (IRS) (6). The previous study demonstrated that IRS-mediated signaling in response to ex vivo exposure to insulin was attenuated in the aorta of genetically obese diabetic Zucker fatty rats (2). We have recently reported that tetrahydrobiopterin $\left(\mathrm{BH}_{4}\right)$, the natural and essential cofactor of nitric oxide synthases (NOS), plays a crucial role not only in increasing the

*Corresponding author. FAX: +81-77-548-2183

E-mail: okamura@belle.shiga-med.ac.jp rate of nitric oxide (NO) generation by NOS but also in controlling the formation of superoxide anion $\left(\mathrm{O}_{2}^{-}\right)$in the endothelial cells (7). In vasculature, insulin stimulates $\mathrm{BH}_{4}$ synthesis through activation of GTP cyclohydrolase $\mathrm{I}$, the rate-limiting enzyme in de novo synthesis of $\mathrm{BH}_{4}$, and either activity or mRNA expression of GTP cyclohydrolase I is suggested to be decreased in the insulin-resistant state (7). The $\mathrm{BH}_{4}$ treatment was associated with a 2-fold increase in eNOS activity as well as a $70 \%$ reduction of endothelial $\mathrm{O}_{2}^{-}$ production compared to those in fructose-induced insulin-resistant rats (fructose-fed rats). Moreover, $\mathrm{BH}_{4}$ treatment of the fructose-fed rats markedly reduced the lipid peroxide content which is increased in fructose-fed rats. Furthermore, increased binding activity of two redox-sensitive transcription factors, nuclear factor $-\kappa \mathrm{B}$ and activating protein-1, in fructose-fed rats was also 
prevented by the treatment with $\mathrm{BH}_{4}$. However, $\mathrm{BH}_{4}$ treatment did not normalize blood pressure in the insulin-resistant state (8). These findings suggest that an additional element to regulate vascular tone is therefore likely to be present in the insulin-resistant state.

The vascular tone is regulated by a variety of autocrine and paracrine systems localized in the endothelial and smooth muscle cells. It has been reported that blockade of the renin-angiotensin system with angiotensin converting enzyme (ACE) inhibitors and angiotensin II (Ang II) type 1 (AT1)-receptor antagonists have benefical effects on patients with insulin resistance $(9-11)$. The GISSI-3 study demonstrated that diabetic patients benefited more from ACE inhibitiors than nondiabetic patients did, independent of other risk factors for elevated mortality (12). Recent comparative trials in patients with type 2 diabetes and hypertension have suggested that for the prevention of cardiovascular events, ACE inhibitors may be superior to alternative antihypertensive agents $(13,14)$. Reduction in cardiovascular events with ACE inhibitors was much greater (almost 50\%) than that expected from blood pressure reduction alone compared with placebo, supporting the view that additional mechanisms contribute to the prevention of cardiovascular events with ACE inhibition.

In this review, we are going to address the molecular mechanisms responsible for the modulation of the reninangiotensin system in the insulin-resistant state.

\section{The NAD(P)H oxidases as major sources of vascular $\mathrm{O}_{2}^{-}$in the insulin-resistant state}

Among many enzymatic systems that are capable of producing reactive oxygen species (ROS), NAD(P)H oxidase and uncoupled eNOS have been extensively studied in vascular cells. Of note, eNOS constitutively produces both $\mathrm{NO}$ and $\mathrm{O}_{2}{ }^{-}$, suggesting that the effective release of NO from the vascular endothelium depends on the relative concentrations of these two radical species. It is generally recognized that the $\mathrm{NAD}(\mathrm{P}) \mathrm{H}$ oxidases are predominant sources of $\mathrm{O}_{2}^{-}$in the vasculature. We measured the vascular $\mathrm{O}_{2}^{-}$production in the absence of EDTA using intact aortic segments. As a result, aortic segments in the absence of EDTA showed a 1.7-fold elevation of the basal $\mathrm{O}_{2}^{-}$production compared with those in the presence of EDTA (15). Thus, both calciumindependent and -dependent (primarily eNOS-derived) enzymatic systems are likely to be sources of $\mathrm{O}_{2}^{-}$production.

In fructose-fed rats, vascular $\mathrm{O}_{2}^{-}$production measured in the presence of EDTA was increased 1.5-fold compared with control rats. Incubation of vessels with either apocynin or diphenyleniodinium (DPI) markedly attenuated the $\mathrm{O}_{2}^{-}$production, whereas oxypurinol, rotenone, indomethacin, nordihydroguaiaretic acid (NDGA), or $N^{\mathrm{G}}$-nitro-L-arginine (L-NA) were ineffective. Therefore, it appears that $\mathrm{NAD}(\mathrm{P}) \mathrm{H}$ oxidase is a major source of $\mathrm{O}_{2}^{-}$generation in these vessels, whereas the yield of $\mathrm{O}_{2}^{-}$and lipid hydroperoxide from the lipoxygenase and/or cyclooxygenase pathway is much less than that from $\mathrm{NAD}(\mathrm{P}) \mathrm{H}$ oxidase. $\mathrm{NAD}(\mathrm{P}) \mathrm{H}$ oxidase has recently been demonstrated to be the predominant $\mathrm{O}_{2}^{-}$source in both endothelial and smooth muscle cells $(16,17)$. Endothelial removal produced no significant reduction in $\mathrm{NAD}(\mathrm{P}) \mathrm{H}$ oxidase activities in homogenates from control rats, while this caused marked reduction of the enzyme activities in homogenates from fructose-fed rats. These findings indicate that the insulin-resistant state results in enhanced $\mathrm{NAD}(\mathrm{P}) \mathrm{H}$ oxidase activities only in the presence of endothelium.

\section{Modulation of vascular renin-angiotensin system in the insulin-resistant state}

There are two major subtypes of Ang II receptors, AT1, AT2; and AT1 receptors are further subdivided into AT1a and AT1b receptors in the rodent (18). ACE inhibitors and AT1-receptor antagonist have been noted to improve vascular reactivity in the insulin-resistant state $(15,19)$. These evidence suggest that AT1mediated Ang II signaling is essential for the maintenance of systemic blood pressure in the insulin-resistant state.

Ang II is the major effector substance of the reninangiotensin system and has effects in the CNS, heart, vasculature, and kidney (20). G-protein-coupled membrane oxidases are known to be responsible for the generation of $\mathrm{O}_{2}^{-}$at the cell surface such as activation of NADPH oxidase by an amyloidogenic peptide in neurons (21) or by Ang II in vascular endothelial and smooth muscle cells (22). To gain insights into how insulin resistance increases the oxidase activity, Ang IIinduced vasoconstricting responses were assessed in vivo and in vitro. The contractile response to Ang II was enhanced in the fructose-fed rats compared with the control rats (15). We could not find any difference in vasoconstrictor response to L-phenylephrine. In addition, in the present study, AT1-receptor blockade inhibited NAD(P)H oxidase activities and the Ang IIinduced vasoconstriction and in parallel improved endothelial dysfunction in the insulin-resistant state. Thus, it is reasonably speculated that the insulin-resistant state is related to overfunction of Ang II, probably due to upregulation of AT1-receptor number and affinity for the agonist. 
Since the lack of discriminatory pharmacological antagonists made it impossible to define the individual functions of the two AT1-receptor subtypes (AT1a and AT1b), we examined the pathophysiological roles of AT1 receptor using AT1a-receptor knockout (AT1a KO) mice. We found that AT1a-receptor expression was dramatically increased in aortic tissues from insulinresistant mice (15). The increase in Ang II-receptor expression was entirely due to an increase in AT1a expression, because expression of both AT1b and AT2 receptor was unaltered. In the vascular wall, Ang II induces vasoconstriction by a direct action on smooth muscle cells, but this effect might be modulated by Ang II interaction with endothelial cells. We demonstrated that endothelial removal produced a slight reduction of $\mathrm{O}_{2}^{-}$levels in vessels from control rats, while the marked reduction of $\mathrm{O}_{2}^{-}$production was found in vessels from fructose-fed rats. In addition, endothelial removal produced no significant reduction in $\mathrm{NAD}(\mathrm{P}) \mathrm{H}$ oxidase activities in homogenates from control rats, while there was marked reduction of these enzyme activities in homogenates from fructose-fed rats. These data indicate that the insulin-resistant state may stimulate the generation of $\mathrm{O}_{2}^{-}$through the activation of $\mathrm{NAD}(\mathrm{P}) \mathrm{H}$ oxidase in aortic endothelial cells under in vivo conditions.

AT1-receptor blockade normalized both $\mathrm{NAD}(\mathrm{P}) \mathrm{H}$ oxidase activities and vascular $\mathrm{O}_{2}^{-}$production in fructose-fed rats. In addition, losartan treatment resulted in markedly elevated plasma Ang II compared with control rats (15). AT1-receptor blockade interferes with the negative feedback of Ang II on the release and synthesis of renin from the kidneys, leading to an increase in Ang II levels (23). A recent in vitro study has shown that AT2 receptor functionally antagonizes the AT1 receptor-induced endothelial $\mathrm{O}_{2}^{-}$production by a pathway involving tyrosine phosphatases (24). Consequently, increased stimulation of AT2 receptors during AT1-receptor blockade may inhibit endothelial $\mathrm{O}_{2}{ }^{-}$ production in these rats.

\section{Insulin resistance and modulation of vascular NAD(P)H oxidases}

Because the stimulation of AT1a receptor by Ang II leads not only to direct activation of the $\mathrm{O}_{2}^{-}$-generating

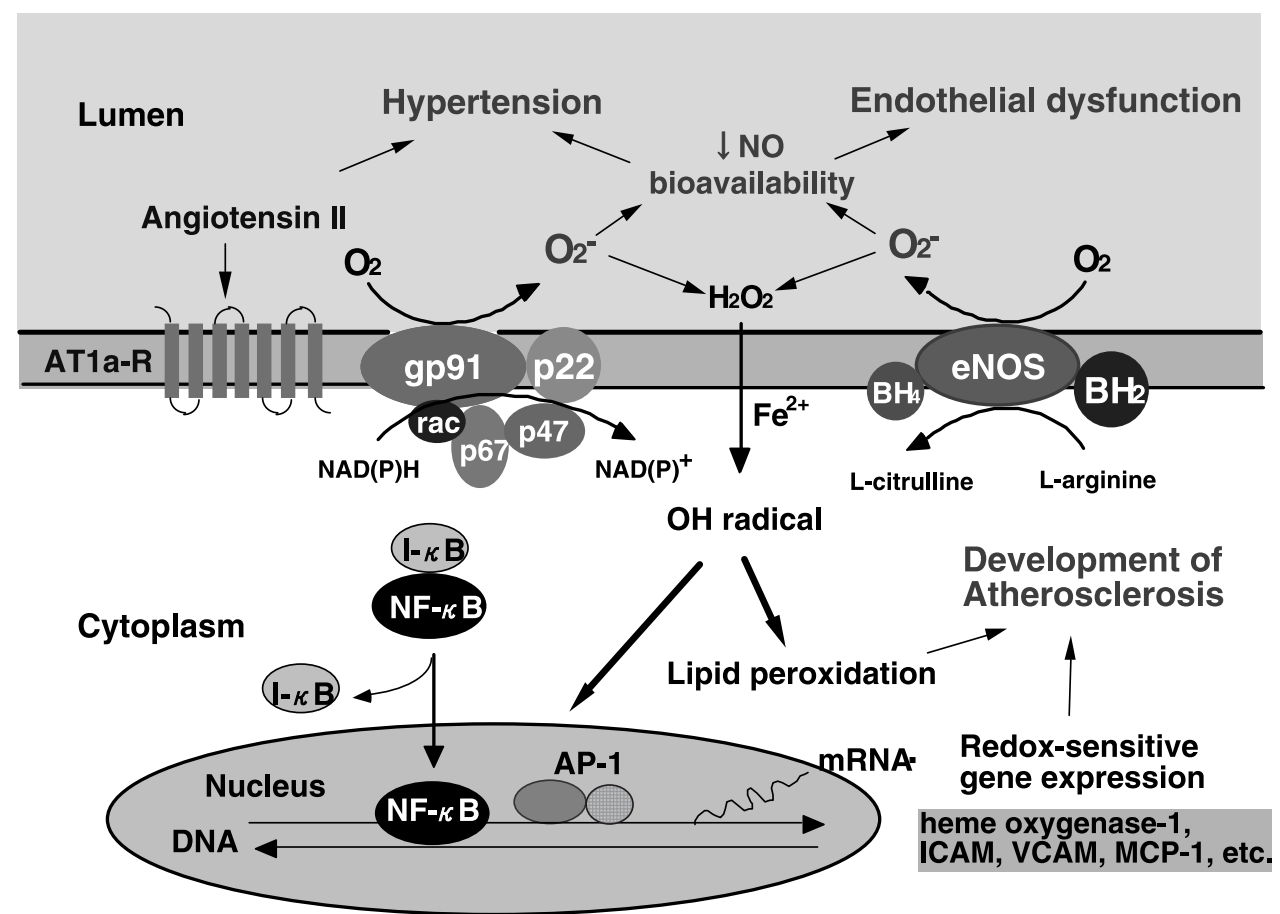

Fig. 1. Schematic model depicting the close association of enhanced formation of superoxide anion $\left(\mathrm{O}_{2}^{-}\right)$and impaired endothelium-dependent arterial relaxation in the insulin-resistant state. Overactivity of the vascular renin-angiotensin system and uncoupling of endothelial nitric oxide (eNOS) is likely to increase endothelial $\mathrm{O}_{2}{ }^{-}$production and contribute in part to the pathogenesis of endothelial dysfunction and hypertension in the insulin-resistant state. AT1a-R, angiotensin II type 1a receptor; $\mathrm{NO}$, nitric oxide; $\mathrm{BH}_{4}$, tetrahydrobiopterin; $\mathrm{BH}_{2}, 6,7(8 H)$-dihydrobiopterin; $\mathrm{H}_{2} \mathrm{O}_{2}$, hydrogen peroxide; $\mathrm{OH}$ radical, hydroxy radical; NF- $\kappa \mathrm{B}$, nuclear factor-kappaB; I- $\kappa \mathrm{B}$, I-kappaB; AP-1, activating protein-1; ICAM, intercellular adhesion molecule-1; VCAM, vascular cell adhesion molecule-1; MCP-1, monocyte chemoattractant protein-1. 
NAD $(\mathrm{P}) \mathrm{H}$ oxidase but also to an enhanced expression of essential subunits (p22 $2^{\text {phox }}$, gp9 $91^{\text {phox }}, \mathrm{p} 67^{\text {phox }}$ ) of this enzyme, the decreased expression of these subunits in the aorta of fructose-fed AT1a KO mice may well contribute to the observed reduction of vascular $\mathrm{O}_{2}^{-}$ production and $\mathrm{NAD}(\mathrm{P}) \mathrm{H}$ oxidase activities. Using molecular biological approaches, the presence of mRNAs for $\mathrm{gp} 91^{\text {phox }}, \mathrm{p} 22^{\text {phox }}, \mathrm{p} 47^{\text {phox }}$, and $\mathrm{p} 67^{\text {phox }}$ has been demonstrated in endothelial cells and adventitial cells (25). Vascular smooth muscle cells appear to express $\mathrm{p} 22^{\text {phox }}$ and $\mathrm{p} 47^{\text {phox }}$, but not gp $91^{\text {phox }}$ and $\mathrm{p} 67^{\text {phox }}$ (26). Indeed, gp91 phox appears to be crucial for the endothelial $\mathrm{O}_{2}^{-}$production, because knockout of the gp91 $1^{\text {phox }}$ gene abolished $\mathrm{O}_{2}^{-}$production in endotheliumintact aortic segments and exhibited a more pronounced endothelium-dependent relaxation than that observed in aorta from WT mice (27). Therefore, our findings in rodent vessels support a potential mechanistic relationship between upregulation of AT1 receptors and $\mathrm{NAD}(\mathrm{P}) \mathrm{H}$ oxidase-dependent endothelial $\mathrm{O}_{2}^{-}$production, proposed on the basis of similar findings in human blood vessels from diabetic patients (28).

\section{Conclusions}

In a series of our recent work, we describe the role of vascular insulin resistance in the pathogenesis of endothelial dysfunction. These results indicate that generation of $\mathrm{O}_{2}^{-}$from $\mathrm{NAD}(\mathrm{P}) \mathrm{H}$ oxidases and an uncoupled eNOS may be pathogenic factors for impaired endothelial function and increased vascular tone in the insulin-resistant state. Vascular insulin resistance might induce an impaired pteridine metabolism and activated renin-angiotensin system (Fig. 1). Even though the relative importance of the various possible mechanisms leading to the depressed endothelial function in the insulin-resistant state remains to be elucidated, our study shows that $\mathrm{BH}_{4}$ augmentation and blockade of the renin-angiotensin system results in the restoration of endothelial function and vascular tone in the insulin-resistant states.

\section{Acknowledgment}

This research was supported in part by a Grant-inAid for Encouragement of Young Scientist (Grant \#14770598) from the Ministry of Education, Culture, Sports, Science, and Technology, Japan.

\section{References}

1 Wheatcroft SB, Williams IL, Shah AM, Kearney MT. Pathophysiological implications of insulin resistance on vascular endothelial function. Diabet Med. 2003;20:255-268.

2 Jiang ZY, Lin YW, Clemont A, Feener EP, Hein KD, Igarashi $\mathrm{M}$, et al. Characterization of selective resistance to insulin signaling in the vasculature of obese Zucker (fa/fa) rats. J Clin Invest. 1999; 104:447-457.

3 Sugita M, Sugita H, Kaneki M. Increased insulin receptor substrate 1 serine phosphorylation and stress-activated protein kinase/c-jun N-terminal kinase activation associated with vascular insulin resistance in spontaneously hypertensive rats. Hypertension. 2004;44:1-6.

4 Shinozaki K, Kashiwagi A, Masada M, Okamura T. Stress and vascular responses: oxidative stress and endothelial dysfunction in the insulin-resistant state. J Pharmacol Sci. 2003;91:187-191.

5 Shinozaki K, Kashiwagi A, Masada M, Okamura T. Molecular mechanisms of impaired endothelial function associated with insulin resistance. Curr Drug Targets Cardiovasc Haemat Dis. 2004;4:1-11.

6 White MF. IRS proteins and the common path to diabetes. Am J Physiol Endocrinol Metab. 2002;283:E413-E422.

7 Shinozaki K, Kashiwagi A, Nishio Y, Okamura T, Yoshida Y, Masada M, et al. Abnormal biopterin metabolism is a major cause of impaired endothelium-dependent relaxation through nitric oxide $/ \mathrm{O}_{2}^{-}$imbalance in insulin-resistant rat aorta. Diabetes. 1999;48:2437-2445.

8 Shinozaki K, Nishio Y, Okamura T, Yoshida Y, Maegawa H, Kojima $\mathrm{H}$, et al. Oral administration of tetrahydrobiopterin prevents endothelial dysfunction and vascular oxidative stress in aortas of insulin-resistant rats. Circ Res. 2000;87:566-573.

9 Cheetham C, Collis J, O’Driscoll G, Stanton K, Taylor R, Green D. Losartan, an angiotensin type1 receptor antagonist, improves endothelial function in non-insulin-dependent diabetes. J Am Coll Cardiol. 2000;36:1461-1466.

10 Estacio RO, Jeffers BW, Hiatt WR, Biggerstaff SL, Gifford $\mathrm{N}$, Schrier RW. The effect of nisoldipine as compared with enalapril on cardiovascular outcomes in patients with noninsulin-dependent diabetes and hypertension. $\mathrm{N}$ Engl $\mathrm{J}$ Med. 1998;338:645-652.

11 Hansson L, Lindholm LH, Niskanen L, Lanke J, Hedner T, Niklason A, et al, for the Captopril Prevention Project (CAPPP) study group. Effect of angiotensin-converting-enzyme inhibition compared with conventional therapy on cardiovascular morbidity and mortality in hypertension: the Captopril Prevention Project (CAPPP) randomized trial. Lancet. 1999;353:611616

12 Zuanetti G, latini R, Maggioni A, Franzosi M, Santoro L, Tognoni G, on behalf of the GISSI-3 Investigators. Effects of ACE-inhibitor lisinopril on mortality in diabetic patients with acute myocardial infarction: data from the GISSI-3 study. Circulation. 1997;96:4239-4245.

13 Pahor M, Psaty BM, Furberg CD. Treatment of hypertensive patients with diabetes. Lancet. 1998;351:689-690.

14 Pahor M, Psaty BM, Furberg CD. New evidence on the prevention of cardiovascular events in hypertensive patients with type 2 diabetes. J Cardiovasc Pharmacol. 1998;32 Suppl 2:S18-S23.

15 Shinozaki K, Ayajiki K, Nishio Y, Sugaya T, Kashiwagi A, Okamura T. Evidence for a causal role of rennin-angiotensin system in vascular dysfunction associated with insulin resistance. Hypertension. 2004;43:255-262.

16 Griendling KK, Minieri CA, Ollerenshaw JD, Alexander RW. Angiotensin II stimulates NADH and NADPH oxidase activity 
in cultured vascular smooth muscle cells. Circ Res. 1994;74: $1141-1148$

17 Mohazzab KM, Kaminski PM, Wolin MS. NADH oxidoreductase is a major source of superoxide anion in bovine coronary endothelium. Am J Physiol. 1994;266:H2568-H2572.

18 Timmermans PBMWM, Wong PC, Chiu AT, Herbin WF, Benfield P, Carini DJ, et al. Angiotensin II receptors and angiotensin II receptor antagonists. Pharmacol Rev. 1993;45:205-251.

19 Navarro-Cid J, Maeso R, Perez-Vizcaino F, Cachofeiro V, Ruilope LM, Tamargo J, et al. Effects of losartan on blood pressure, metabolic alterations, and vascular reactivity in the fructose-induced hypertensive rat. Hypertension. 1995;26:10741078.

20 Lavoie JL, Sigmund CD. Minireview: overview of the renninangiotensin system - an endocrine and paracrine system. Endocrinology. 2003;144:2179-2183.

21 Thomas T, Thomas G, McLendon C, Sutton Tmullan M. $\beta$ Amyloid-mediated vasoactivity and vascular endothelial damage. Nature. 1996;380:168-171.

22 Rajagopalan S, Kurz S, Münzel T, Tarpey M, Freeman BA, Griendling KK, et al. Angiotensin II-mediated hypertension in the rat increases vascular superoxide production via membrane NADH/NADPH oxidase activation: contribution to alterations of vascular tone. J Clin Invest. 1996;97:1916-1923.

23 van den Meiracker AH, Admiraal PJ, Janssen JA, Kroodsma
JM, de Ronde WA, Boomsma F, et al. Hemodynamic and biochemical effects of the AT1 receptor antagonist irbesartan in hypertension. Hypertension. 1995;25:22-29.

24 Sohn HY, Raff U, Hoffmann A, Gloe T, Heermeier K, Galle J, et al. Differential role of angiotensin II receptor subtypes on endothelial superoxide formation. Br J Pharmacol. 2000;131: 667-672.

25 Jones SA, O'Donnell VB, Wood JD, Broughton JP, Hughes EJ, Jones OTG. Expression of phagocyte NADPH oxidase components in human endothelial cells. Am J Physiol. 1996;271: H1626-H1634.

26 Patterson C, Ruef J, Madamanchi NR, Barry-Lane P, Hu Z, Horaist C, et al. Stimulation of a vascular smooth cell NAD(P)H oxidase by thrombin: evidence that $\mathrm{p} 47$ (phox) may participate in forming this oxidase in vitro and in vivo. J Biol Chem. 1999; 274:19814-19822.

27 Gorlach A, Brandes RP, Nguyen K, Amidi M, Dehghani F, Busse R. A gp91 phox containing NADPH oxidase in endothelial cells is a major source of oxygen radical generation in the arterial wall. Circ Res. 2000;87:26-32.

28 Guzik TJ, Mussa S, Gastaldi D, Sadowski J, Ratnatunga C, Pillai R, et al. Mechanisms of increased vascular superoxide production in human diabetes mellitus. Role of $\mathrm{NAD}(\mathrm{P}) \mathrm{H}$ oxidase and endothelial nitric oxide synthase. Circulation. 2002;105:1656-1662. 